\title{
Role Bargaining Strategies for China's Peaceful Rise
}

\author{
Kai He and Stephen Walker
}

\begin{abstract}
The bargaining for a new role in world politics presents a rising power with a strategic dilemma, as the new role entails a new power position in the system and a new social status in international society. China’s assertiveness in diplomacy after 2008 can be seen as a “role bargaining” process between China and the outside world, such as China's bargaining for a new role in the global financial system through the Asian Infrastructure Investment Bank (AIIB). This paper aims to examine how a rising power can bargain for the new role in a peaceful way. Based on rational bargaining theory and on role theory, we suggest four strategies whereby a rising power bargains for a new role: costly signalling, self-restraint, role-diversification, and alter-casting. Through focusing on China's WTO accession and integration into the global economy after the Cold War, we examine the utilities and limitations of these four rolebargaining strategies for a rising power in the international system. The first two strategies aim to address the information and commitment problems concomitant with rationalism that a rising power faces in negotiating a new power position, and the last two strategies focus on how a rising power can bargain for a new social role by balancing the self's role conception and the role expectations of others.
\end{abstract}

China's rise is one of the defining political events in $21^{\text {st }}$ century world politics. Scholars and pundits alike are fascinated with the implications of China's rise for international relations. While some suggest that China's rise will lead to an inevitable conflict as a consequence of the power transition between a rising power and the existing hegemon, others argue that this might not be the case, due either to economic interdependence, or international institutions, or the diffusion of globalization norms. ${ }^{1}$ Borrowing insights from role theory and bargaining theory, this paper suggests that China's rise is a bargaining process between China and the outside world regarding China's new role in the international system, and that it is still too early to be either optimistic or pessimistic about the final outcome of China’s rise.

\footnotetext{
${ }^{1}$ For an excellent review of optimistic vs. pessimistic views on China's rise, see Aaron Friedberg, 'The Future of U.S.-China Relations', International Security 30, no. 2 (2005), 7-45
} 
Historically, war or conflict is a normal means for a rising power to adjust its role in the international system, as we have witnessed from the failed attempts of Germany and Japan in this respect in World War II. However, we also observe that the United States was not involved in large-scale wars with Great Britain during its ascent to world power status, even though its territorial expansion resulted in military conflicts with Mexico and Spain. ${ }^{2}$ In a similar vein, Prussia-Germany under Bismarck became the most powerful and influential state in Europe in the mid- $19^{\text {th }}$ century without military interventions from either Russia or Great Britain. ${ }^{3}$ Although geographical and structural reasons contributed to the relatively peaceful rise of the United States and Prussia in the $19^{\text {th }}$ century, there is no denying that their respective rising strategies played an important part in alleviating antagonism from other countries. When explaining Prussia’s relatively peaceful rise, Paul Kennedy points out that 'the flank powers' [Russia and Great Britain] likelihood of intervening in the affairs of west-central Europe would depend heavily on what Germany itself did; there was certainly no need to become involved if it would be assumed that the second German Reich was now a satiated power'. 4

In this paper we focus on examining how a rising power can bargain for a new role with the outside world without wars and conflicts. Through integrating role theory and bargaining theory, we suggest four strategies: costly signalling, self-constraint, role-diversification, and alter-casting, which can facilitate a rising power's negotiation of a new role in a tranquil way. The first two strategies aim to alleviate the information and commitment problems inherent in bargaining theory and the latter two are inspired by role theory, which emphasizes the balance of self's role conception and the role expectations of others in a social environment. Although a rising power's strategy is by no means the only determinant, we suggest that how a rising power behaves is one of the most important factors in shaping the final outcome of the role transition process in the international system.

This paper has four sections. First, we introduce four strategies rooted in role theory and bargaining theory for a rising power to bargain for a role transition in a peaceful way. Second, we explore how China employed these four strategies to reach bargaining deals during China's

\footnotetext{
${ }^{2}$ See Kenneth Bourne, The Balance of Power in North America (Berkeley: University of California Press, 1967); Colin Elman, 'Extending Offensive Realism: The Louisiana Purchase and America’s Rise to Regional Hegemony', American Political Science Review 98, no. 4 (2004), 563-76.

${ }^{3}$ See Paul Kennedy, The Rise and Fall of the Great Powers (N.Y.: Random House, 1987).

${ }^{4}$ Kennedy, The Rise and Fall of the Great Powers, 189.
} 
accession to the WTO in particular and its integration into the global economy in general. We then discuss the challenges to China's future bargaining with the United States in light of the post-2008 'assertive turn’ in China’s diplomacy.In conclusion, we suggest that future research should integrate practice theory with role theory and rational choice theory in examining role bargaining practices through diplomacy between China and the outside world.

\section{China's Role Bargaining Strategies}

China's rise has triggered much theoretical and policy debate among IR scholars and policy practitioners since the early 1990s. Most research focuses on whether or not China's rise will be peaceful; there is limited attention to the question of how China can rise peacefully in the international system. Although a rising power will undoubtedly challenge the existing international order, this does not mean that military conflicts between the rising power and the hegemon are inevitable. As mentioned above, both Prussia under Bismarck and the United States rose on the stage of world politics in the $19^{\text {th }}$ century without large-scale conflicts or wars. Therefore, power transition alone cannot determine the final outcome of a country's rise. For China's rise, the likelihood of interventions from the United States and other major powers depends to a significant extent on what China will do, i.e., China's future strategic choices in pursuing its rise.

Through integrating role theory and bargaining theory, this paper focuses on exploring strategic choices whereby a rising power transforms its role in the international system. Role theory is not a single theory but a research programme that includes many theories and perspectives sharing a similar view on the importance of the concept of role in social life. The 'role' concept is a metaphor borrowed from the theatre. Role theorists suggest that everyone plays a certain societal role or roles through which society functions as a web composed of the roles of individuals. Role theory had been in use for four decades, in sociology, social psychology, and anthropology, before it was introduced to foreign policy analysis and international relations in the 1970s. ${ }^{5}$ A major contribution of role theory to foreign policy analysis is that of providing a unique framework to integrate different theoretical perspectives,

\footnotetext{
${ }^{5}$ K. J. Holsti, 'National Role Conceptions in the Study of Foreign Policy’, International Studies Quarterly 14, no.3, (1970), 233-309; Stephen G. Walker, ed. Role Theory and Foreign Policy Analysis (Durham, NC: Duke University Press1987); Cameron G. Thies, 'Role theory and Foreign Policy’ in The International Studies Encyclopedia, edited by Robert Denmark (Oxford: Blackwell, 2010).
} 
such as realism, liberalism, and constructivism, into the study of foreign policy. ${ }^{6}$ As Cameron Thies suggests, role theory has the potential to link different levels of analysis in Foreign Policy Analysis as well as to connect agents and structures in International Relations, although the intellectual value of role theory is also either overlooked or questioned in the IR field. ${ }^{7}$

In the debate about China's rise, scholars from different schools of thought disagree over the question, 'what will China want?' Realists suggest that China will want power and domination; liberals believe that more wealth and a new China-centred order may be the correct answers. Constructivists highlight the importance of ideas and identity, suggesting that China will want higher status and more respect in the ideational system. All these answers are valid to a certain extent. However, they only focus on one or certain selected aspects of China's strategic goals. Therefore, role theory provides a new analytical framework to bridge the intellectual gap between agents and structure as well as among different theoretical paradigms. Role theory suggests that China will want a new 'role' in international society, one that entails power, wealth, status, and a new identity.

Moreover, role theorists argue that the new 'role' for China to pursue is shaped by the interaction among at least three factors. First, the agent (China) needs to define its new role through its self-conception, i.e., what China wants to be in international society. Second, other states can have role expectations of China, i.e., what they want China to become. Third, international society imposes the 'role demands' of the system on China, i.e., constraints and

6 See Stephen G. Walker, 'Binary Role Theory: Reducing Uncertainty and Managing Complexity in Foreign Policy Analysis', in Rethinking Foreign Policy Analysis: States, Leaders, and the Microfoundations of Behavioral International Relations, eds. Stephen G. Walker, Akan Malici, and Mark Schafer (New York: Routledge, 2011), 244-266; Stephen G. Walker, Role Theory and the Cognitive Architecture of British Appeasement Decisions: Symbolic and Strategic Interaction in World Politics (New York: Routledge, 2013); Cameron Thies and Marijke Breuning, 'Integrating Foreign Policy Analysis and International Relations through Role Theory’, Foreign Policy Analysis 8, no. 1 (2012), 1-4; Sebastian Harnisch, 'Conceptualizing in the Minefield: Role Theory and Foreign Policy Learning’, Foreign Policy Analysis, 8, no. 1(2012), 47-69; Marijke Breuning, 'Role Theory Research in International Relations', in Role Theory Research in International Relations: Conceptual Challenges and Political Promise, eds. Sebastian Harnisch, Cornelia Frank, and Hanns W. Maull. London and New York: Routledge (2011), 16-35.

${ }^{7}$ See Thies, 'Role theory and Foreign Policy'. 
incentives. ${ }^{8}$ Here, China's role is shaped explicitly by both agents (including China and other states) and the structure of the international system. Role theorists normally focus on the convergence or divergence of an agent's role conception vs. role expectations from others as well as the system's role demands.

Thies points out that an agent's role location is the product of a process of socialization or bargaining between the agent and the outside world. Thies creatively introduces the 'role socialization game' in which he highlights the possible negotiation pathways whereby an agent is socialized into the system. ${ }^{9}$ Based on this role negotiation or socialization assumption we integrate rationalist bargaining theory into the role theory framework. Rational bargaining theory suggests that wars or conflicts are suboptimal outcomes or failed bargaining deals between states, because it is not normally rational for states to fight in the first place. Applying role theory and bargaining theory to China's rise, we can assume that China intends to negotiate a new role in the system through a bargaining process. Conflicts or wars between China and the outside world are not inevitable so long as China can reach a bargaining deal with the outside world on its new role. Therefore, the real question is, how can China bargain for a new role in a peaceful way?

Bargaining theories raise two obstacles to successful bargaining: information and commitment problems. The information problem refers to asymmetric information between the two states in a bargaining process. Each state has its private information that is not shared with others. Such private information includes a state's own capability, true resolve, and bottom-line position for negotiations. To further complicate the situation, states are not only encouraged to hide their private information; they also have incentives to misrepresent their private information, such as by exaggerating their military capabilities and resolve, to reach a better deal during negotiations. ${ }^{10}$

\footnotetext{
${ }^{8}$ There are also other mechanisms, such as audience effects and role location, in role theory. See Thies, 'Role theory and Foreign Policy', and Stephen G. Walker, 'Symbolic Interactionism and International Politics: Role Theory's Contribution to International Organization', in Contending Dramas: A Cognitive Approach to International Organizations, eds., Martha Cottam and Chih-yu Shih (New York: Praeger, 1992), 19-38.

${ }^{9}$ Cameron G. Thies, 'International Socialization Processes vs. Israeli National Role Conceptions: Can Role Theory Integrate IR Theory and Foreign Policy Analysis', Foreign Policy Analysis, 8 (2012), 25-46; and The United States, Israel, and the Search for International Order: Socializing States (London and New York: Routledge, 2013).

${ }^{10}$ For a rationalist bargaining theory, see Thomas Schelling, The Strategy of Conflict (Cambridge: Harvard University Press, 1960); James Fearon, 'Rationalist Explanations for War’, International Organization 49, no. 3
} 
Commitment becomes a problem, as James Morrow points out, because 'actors often want to make promises that others doubt the actors will be willing to carry out later' and also because 'actors' incentives change over time'. ${ }^{11}$ Indeed, commitment problems are rooted in the anarchic nature of the international system wherein there is no overarching authority to enforce agreements and punish cheating behaviours. ${ }^{12}$ States in this anarchic international system do not easily believe others’ promises. Nor are they trusted in return by others.

In the role bargaining process a rising power such as China has to address both information and commitment problems in order to reach a bargaining deal with the outside world. Bargaining theory suggests two possible strategies: costly signalling and self-constraint, to alleviate these two problems. First, China as Ego needs to signal its intended role to the outside world, especially to the hegemon as its major Alter in the system. The signal needs to be costly to ensure the credibility of 'private information' through the mechanisms of audience costs and/or sunk costs. ${ }^{13}$ Audience costs refer to political costs that a political leader has to pay if he or she backs down from either a promise or a threat made to the adversary. In international relations, audience costs normally refer to domestic political costs, i.e., a political leader will be punished by domestic political forces, normally via elections, if he or she cannot keep the

(1995), 379-414; Robert Powell, ‘War as a Commitment Problem’, International Organization 60, no. 4 (2006), 169-203. For an example of applying rationalist bargaining theory to China’s case, see Kai He and Huiyun Feng, ‘China’s Bargaining Strategies after the Cold War: Successes and Challenges’, Asian Security 10, no.2 (2014), 168187.

${ }^{11}$ See James Morrow, 'The Strategic Setting of Choices: Signaling, Commitment, and Negotiation in International Politics', in Strategic Choice and International Relations, eds., David Lake and Robert Powell (Princeton: Princeton University Press, 1999), 91-92.

12 See Fearon, 'Rationalist Explanation for War'; and Powell, 'War as a Commitment Problem'.

${ }^{13}$ See James Fearon, ‘Signaling Foreign Policy Interests: Tying Hands Versus Sinking Cost', The Journal of Conflict Resolution 41, no. 1 (1997), 68-90. Some scholars suggest that cheap talk also sometimes matters in bargaining. However, Morrow points out that cheap talk matters only when states resolve the coordination problem, not the collaboration problem, in cooperation. See James Morrow, 'Modeling the Forms of International Cooperation: Distribution versus Information', International Organization 48, no. 2 (1994), 387-423; Robert Trager, 'Diplomatic Calculus in Anarchy: How Communication Matters', American Political Science Review Vol. 104, No. 2 (2010), pp. 347-68. 
promise made in public. ${ }^{14}$ It is also an ex post cost since the cost will occur only if the leader backs down at a later time.

In contrast, 'sunk costs' refer to the ex ante costs that have already been experienced and cannot be recovered. Normally, people can choose to endure 'sunk costs' to signal their resolve. For example, an investor can show his or her sincere intentions as regards an investment project by building a factory in a foreign country. The factory represents the sunk costs that the investor has paid, because it is irretrievable whether or not the investor continues to pour money into the project at a later time. For a political leader the 'sunk costs' refer to the political costs the leader has paid before a negotiation takes place. Because sunk costs cannot be recovered, they can signal the credible resolve of one party to others. ${ }^{15}$

As for the commitment problem, the rising power needs to convince the outside world, especially the hegemon, of its limited goals so that the outside world can accept its newly conceptualized role in the system without worrying about future consequences. One strategy whereby the rising power can address this commitment problem is adoption of a 'self-restraint' policy. Self-restraint can be exercised in both capability and manoeuvrability of capability. First, a rising power can choose to develop defensive weapons instead of offensive ones, if the offensedefence advantage is distinguishable. Through constraining its offensive capabilities, the rising power can strengthen its non-aggressive commitment to the outside world. ${ }^{16}$ Second, a rising power can 'lock' itself 'in' through multilateral institutions and use their rules and norms to

\footnotetext{
${ }^{14}$ For domestic-level audience costs, see Fearon, 'Signaling Foreign Policy Interests: Tying Hands Versus Sinking Cost'. Some scholars expand the application of audience costs to the international level. See Morrow, 'The Strategic Setting of Choices: Signaling, Commitment, and Negotiation in International Politics’. In addition, some scholars argue that leaders in autocracies also face the pressure of audience costs, e.g., Jessica Weeks, 'Autocratic Audience Costs: Regime Type and Signaling Resolve', International Organization 62, no. 4 (2008), 35-64. For critiques of audience costs theory, see Jack Snyder and Erica Borghard, 'The Cost of Empty Threats: A Penny, Not a Pound', American Political Science Review 105, no. 3 (2011), 437-456; Marc Trachtenberg, 'Audience Costs: An Historical Analysis', Security Studies 21, no. 3 (2012), 3-42.

${ }^{15}$ See Fearon, 'Signaling Foreign Policy Interests'.

${ }^{16}$ See Charles Glaser, 'Political Consequences of Military Strategy: Extending and Refining the Spiral Model', World Politics 44, no. 4 (1992), 497-538; Andrew Kydd, 'Sheep in Sheep’s Clothing: Why Security Seekers Do Not
} Fight Each Other', Security Studies 7, no. 1 (1997), 114-155. 
constrain its own behaviour. ${ }^{17}$ For example, after signing the non-proliferation treaty, a country's freedom to develop nuclear weapons would be constrained. Although the 'lock-in' terms may not actually stop a state from going against its promises covertly, the state will nevertheless face a 'reputation cost' if it is caught cheating. ${ }^{18}$

Besides the 'costly signalling' and 'self-constraint' strategies rooted in bargaining theory, role theorists also suggest two strategies that a rising power can use to negotiate a new role in the system. First, a rising power can diversify its roles in international society to gain a better chance of acceptance by others. This strategy is similar to the 'exit option' in bargaining, wherein the party will have the upper hand if it has more options beyond the negotiation deal. As Theodore R. Sarbin and Vernon L. Allen point out, the more roles an individual has in her repertoire the better prepared she is to meet the demands of social life. ${ }^{19}$ Thies also suggests that a skilled role-taker with multiple roles in her role-set has a better chance than the 'novice' role-taker of being socialized into international society. ${ }^{20}$ Therefore, a rising power can diversify its roles in the bargaining process, since more roles will provide it with a better chance of reaching a peaceful deal with the outside world.

In addition, a rising power can employ an 'alter-casting' strategy to legitimate its role in the system. Alter casting refers to a situation where the relevant others cast a social actor in a role and provide cues that elicit corresponding appropriate behaviour. For role theorists, alter casting is a method of socialization where members of the international system cast novices (alters) into roles within an existing social system. ${ }^{21}$ For example, US policymakers have

\footnotetext{
${ }^{17}$ The 'lock-in' term is borrowed from Ikenberry's argument that the hegemon can use institutions to lock other states in the system. See G. John. Ikenberry, After Victory: Institutions, Strategic Restraint, and the Rebuilding of Order after Major Wars (N.J: Princeton University Press, 2001).

${ }^{18}$ Barry Nalebuff, 'Rational Deterrence in an Imperfect World', World Politics 43, no. 3 (1991), 313-35.

${ }^{19}$ Theodore R. Sarbin and Vernon L. Allen, ‘Role Theory’, In Handbook of Social Psychology, 2nd ed., edited by Gardner Lindzey and Elliot Aronson (Reading, MA: Addison-Wesley,1968), 488-567.

${ }^{20}$ Cameron G Thies, Socialization in the International System. Ph.D. dissertation, Arizona State University, 1999. Thies; 'A Social Psychological Approach to Enduring Rivalries', Political Psychology 22, no.4 (2001), 693-725. ${ }^{21}$ See Thies, Socialization in the International System; Sheldon Stryker and Anne Statham, 'Symbolic Interaction and Role Theory', in Handbook of Social Psychology, 3rd ed., edited by Gardner Lindzey and Elliot Aronson (New York: Random House, 1985), 311-378; Bruce J. Biddle, 'Recent Developments in Role Theory', American Review of Sociology 12(1986), 67-92.
} 
encouraged China to become a 'responsible stakeholder'. This is an alter-casting strategy through which the United States imposed a role-responsible stakeholder-on China, with the expectation and corresponding cues whereby China would behave accordingly.

However, we suggest that a rising power, i.e., a novice, can also use the alter-casting strategy to negotiate its new role in the system, whereby the rising power can influence discourses and use prevailing rules and norms to support its demands. Stacie Goddard suggests that a rising power can set a 'rhetorical trap' by using the opposing states' own words to justify its policies. For example, from 1864 to 1871, Prussia mounted a series of wars that fundamentally altered the balance of power in Europe. Yet no balancing coalition emerged to check Prussia's rise. Goddard argues that the reason for this 'underbalancing' is that 'as Prussia expanded, it appealed to shared rules and norms, strategically choosing rhetoric that would resonate with each of the great powers' ${ }^{22}$ Similarly, during the Sudeten crisis in 1938, Adolf Hitler justified his aggressive expansion by using the rhetoric of self-determination earlier espoused by the British. This example of alter casting as a legitimization strategy hampered Great Britain in militarily balancing against Germany before World War II. ${ }^{23}$

In sum, the rising power can rely on four strategies to bargain for a peaceful role transition with the outside world, especially with the hegemon. Through a costly signalling strategy, the rising power can make the self-conception of its new role more credible in a bargaining process. Through a self-restraining strategy, the rising power can convince the hegemon of its limited goals after role negotiation. By diversifying its roles, the rising power can make itself more acceptable to others in a social system. Through an alter-casting strategy, the rising power can legitimate its role conception in the eyes of other states.

It is worth noting that there are two key assumptions when applying role theory and bargaining theory to an examination of a rising power's policy choice for transiting its role in the international system. First, we focus on exploring an agent's policy options while controlling the impact of the structure and norms of the international system. In other words, we assume that a rising power can apply these four strategies to any type of international system, no matter if it is

\footnotetext{
${ }^{22}$ Stacie Goddard, 'When Right Makes Might: How Prussia Overturned the European Balance of Power', International Security 33, no. 3 (2008/09), 110-142

${ }^{23}$ Goddard, 'When Right Makes Might'. See also Robert Jervis, The Logic of Images in International Relations (New York: Columbia University Press, 1989), 5-6.
} 
bipolar, multipolar, or unipolar. Here, we only discuss states' policy choices, not the outcome or the effectiveness of their policy choices.

Second, we assume that war is an inefficient outcome or a failed bargaining outcome among states, and that states have incentives to bargain with each other. This assumption omits many factors in determining peace and war in world politics, such as domestic politics, leadership personality, and nuclear weapons. However, this bargaining assumption simplifies the complex nature of world politics and highlights the role of states' policy choices in shaping world politics. A rising power's role transition strategy does not solely determine whether or not a peaceful bargain can be made. However, we suggest that it is the first, or the most important, step in role transition dynamics in world politics.

\section{China and the WTO: Bargaining for a New Role}

In order to illustrate the utilities of these four strategies, we examine China's bargaining efforts in 2001 towards accession to the World Trade Organization (WTO). It is worth noting that the WTO instance is by no means a 'critical case' to test the validity of either rational bargaining theory or role theory in studies of China's international relations. Instead, it is an 'exemplar case' to demonstrate how China has utilized the different role bargaining strategies to negotiate with the outside world. Economic interaction or trade is the first encounter between China and the outside world. Therefore, it is also the most developed area in which China has fully employed different bargaining strategies. Through examining the successes and challenges of China's bargaining strategies in the economic and trade area, this research can shed light on China's interactions with the outside world in other domains, although security or military issues are admittedly different from economy or trade.

China was a founding member of GATT in 1948, but it withdrew in 1950 after the foundation of the PRC. The reason is rooted in the antagonistic ideology of the West and the East during the Cold War. Due to the 'leaning to one side' policy that Mao Zedong advocated, i.e., allying with the Soviet Union against the West, Chinese leaders set China's National Role Conception (NRC) as a 'revolutionary state', i.e., China aimed to overthrow the West-dominated 
international order. Therefore, that China abandoned its membership of GATT, which was seen as a West-dominated trading regime, was no surprise. ${ }^{24}$

After the Cultural Revolution, Deng Xiaoping initiated in 1978 'economic reform and opening up'. The term 'opening up' signifies Chinese leaders' decision no longer to isolate the nation from the outside world. It also implies a transformation of China's NRC from the early 'revolutionary state’ to an 'integrating state’ or 'integrator', whereby China started to abandon its ideological antagonism towards the West and tried to join international society. Other evidence of China's changing role is the famous slogan, 'Linking up with the international track' that the Chinese government advocated in the late 1980s and the 1990s. As Hongying Wang points out, the slogan implies China's desire to join the international community, which closely linked with the country's efforts to join the WTO. ${ }^{25}$

In 1986, Beijing sought to re-join GATT, predecessor to the WTO. However, the Tian'anmen Incident and the ensuing economic sanctions against China from the West interrupted China's WTO accession negotiations with the outside world. The Tian'anmen Incident and the collapse of the Soviet Union also cautioned Chinese leaders to re-think its NRC, i.e. what China wanted to be in international society. Some advocated a return to the revolutionary path, and warned against Western 'peaceful evolution'. Others, including Deng Xiaoping, insisted on the reformist path through deepening economic reform and opening up. Eventually, the reformist group won the domestic battle inside the Party and the Chinese NRC was re-confirmed as an 'integrator' in the mid-1990s. ${ }^{26}$

However, China’s 'integrator’ role was not easily accepted by other states, i.e., member states of the existing international society. It met with the problem of 'role expectations' from others, i.e. the roles that others expected China to fill. On the one hand, China was still the largest communist country in the world whose economy was tightly controlled by the state. On the other, the WTO is the largest trade liberalization regime, and hence sets and enforces rules for reducing governmental intervention, lowering tariffs, and settling trade disputes. The

\footnotetext{
${ }^{24}$ See Harold Jacobson and Michel Oksenberg, China's Participation in the IMF, World Bank, and GATT: Towards a Global Economic Order (Ann Arbor: University of Michigan Press, 1991).

${ }^{25}$ Hongying Wang, 'Linking Up with the International Track: What’s in a Slogan?’ The China Quarterly, no.189 (2007), 1-23.

${ }^{26}$ See Suisheng Zhao, 'Deng Xiaoping's Southern Tour: Elite Politics in Post-Tiananmen China', Asian Survey 33, no. 8 (1993), 739-756.
} 
discrepancy between China and the WTO complicated China's negotiation of its role with others. In the eyes of other states, especially Western states, China was still an 'outsider' rather than an 'integrator' of international society. ${ }^{27}$

Although China had shown its interest in and desire to join the WTO, how and when other states would be willing to accept China were still in question. Besides operating different economic and trading systems, China’s human rights record, especially the Tian'anmen Incident, tarnished China’s international image. For Western states, therefore, the Chinese government was not only an 'outsider' but also a 'violator' of international norms and rules. The discrepancy between China's role self-conception and others' role expectations resulted in both technological and ideological difficulties regarding China’s joining the WTO. It consequently took 15 years for China to negotiate its 'integrator' role with other members in the system. China employed four strategies, in varying degrees, to integrate itself into international society.

\section{Costly Signalling}

China adopted a costly signalling strategy to confirm its 'integrator' role to the outside world. At the beginning of China's negotiations for WTO accession it insisted on being able to join as a developing country, since this would provide the country more rights and entail fewer obligations to the WTO in terms of tariff reductions and market access. In addition, developing country status would allow China a longer transition period in which to meet the WTO accession demands and comply with trade liberalization commitments, as developing countries have ten years to implement their promised reforms, such as reducing tariffs and protections on agricultural industry, while developed countries have only six years. ${ }^{28}$

Given China’s economic status, especially its GDP per capita, the country was indeed a developing country in the 1990s. In his provocative article 'Does China Matter' in Foreign Affairs, Gerald Segal pointed out that in 1997 China accounted for a mere 3.5 percent of world GNP (the United States share was 25.6 percent), and that its per capita GDP ranking was eighty-one (roughly \$773), positioning China behind even Papua New Guinea. In addition, China made up just three percent of world trade, the same as South Korea

\footnotetext{
${ }^{27}$ See Margaret Pearson, ‘The Case of China’s Accession to the GATT/WTO’, in David Lampton, ed. The Making of Chinese Foreign and Security Policy (Stanford: Stanford University Press, 2001), 337-370.

${ }^{28}$ See Kym Anderson, 'On the Complexities of China’s WTO Accession’, The World Economy 20, no. 6 (1997), 749-772.
} 
and less than Holland-and only 11 percent of total Asian trade. ${ }^{29}$ However, in the eyes of existing WTO members, China's developing country status would generate more troubles than benefits for the international trade regime.

According to the GATT and Uruguay Round Agreements, developing countries enjoy the rights to restrict imports if they face difficulties in their balance of payments or seek to retain protection for a particular 'infant' industry, such as the automobile industry in China. If China used these rights the country's market-opening commitments would become meaningless, and China's WTO access would cause serious damage to the existing trade liberalization regime. Therefore, certain WTO members were unwilling to grant China developing country status, even though China’s economic indicators, especially its GDP per capita, fitted such status. ${ }^{30}$ China’s compromise finally resolved this 'status' stalemate in China's WTO accession negotiations.

As a result, China relinquished the 'special and differential' treatment accorded to developing countries and pledged to fulfil the WTO requirements of a developed country. For example, China agreed to cut its average tariff on industrial products from 24.6 percent to 8.9 percent by 2005. ${ }^{31}$ Meanwhile Argentina maintained the tariff of 30.9 percent, Brazil that of 27 percent, India that of 32 percent, and Indonesia that of 36.9 percent. ${ }^{32}$ In addition, China's tariff levels on certain sensitive agricultural products are lower than Japan's. In the services sector, China committed to all services covered by the WTO General Agreement on Trade in Services (GATS), while only 11 of the 122 WTO members had made such commitments to services by 2000. ${ }^{33}$ US Trade Representative Charlene Barshefsky commented that, 'Very few countries have done this [China’s tariff cuts]' and that China’s commitments to liberalize its distribution

\footnotetext{
${ }^{29}$ Gerald Segal, ‘Does China Matter?’ Foreign Affairs 78, no. 5 (1999), 24-36.

${ }^{30}$ See Anderson, 'On the Complexities of China’s WTO Accession'.

${ }^{31}$ Mark A Groombridge, ‘China’s Long March to a Market Economy’, Executive Summary, Cato Trade Policy Analysis, No. 10, April 2000, p.6.

${ }^{32}$ General Agreement on Tariff and Trade, The Results of the Uruguay Round of Multilateral Trade Negotiation: Market Access for Goods and Services: Overview of the Results, app. Table 6. Cited from Nicholas Lardy, Integrating China into the Global Economy (Washington D.C.: Brookings Institution Press, 2002), p. 79.

${ }^{33}$ WTO, 'Summary of Specific Commitments’ (www.wto.org/wto/services/websum.htm [12 June, 2000].
} 
system were 'broader actually than any World Trade Organization member has made'. ${ }^{34}$ In short, China committed itself more profoundly than most other members in the most sectors.

China's unprecedented compromise in the WTO negotiation is a costly signal strategy through which China delivered credible 'private information' regarding its 'integrator' role. As previously mentioned, private information is the bottom-line information for a party in the negotiations, and it should be costly in order to be credible in the eyes of other parties. China's liberalization commitments regarding tariff cuts and its acceptance of the developed country's accession conditions would bring profound economic and political costs to Chinese society. On the one hand, China's state-owned and less efficient industries would have to go through painful structural transitions and adjustments that would worsen China's unemployment rates in some sectors and regions. On the other, Chinese leaders would face political pressure from certain social and interest groups that lost the most in the trade liberalization process.

It is reported that Premier Zhu Rongji worked during his visit to United States in April 1999 to achieve a deal with the United States on China's WTO accession through a series of concessions. However, the Clinton administration rejected Zhu's offer. Moreover, the United States publicized certain of the Chinese concessions that Zhu had proposed. Consequently Zhu was harshly criticized both within the Party and in Chinese society. ${ }^{35}$ It is clear that for Chinese leaders such as Zhu, China's concessions to the WTO entailed audience costs for their political careers. If they failed to deliver what they promised, i.e., a successful accession to the WTO, they would have to face punishments from their constituency or interest groups. Eventually, China's concessions convinced other states of its resolve to become an 'integrator' in international society. In 1999, less than one year after Zhu's visit to the United States, China reached its agreement with the United States on China's WTO accession. This removed the last hurdle on China's journey to the WTO.

\footnotetext{
${ }^{34}$ US Trade Representative, 'Market Access and Protocol Commitments', undated manuscript distributed by USTR after Premier Zhu Rongji's April 1999 visit to the United States, p.6. And Charlene Barshefsky, 'US Trade Policy in China', hearing before the Senate Finance Committee on the Status of China's Application to Join the World Trade Organization, 13 April, 1999 (www.fnsg.com).

${ }^{35}$ See Robert Suettinger, Beyond Tiananmen: The Politics of U.S.-China Relations, 1989-2000 (Washington D.C.: The Brookings Institution, 2003); also Robert Lawrence Kuhn, The Man Who Changed China: The Life and Legacy of Jiang Zemin, (New York: Crown Publishing Group, 2004).
} 


\section{Self-Restraint}

The purpose of a self-restraint strategy is to strengthen the credibility of what one negotiation party has promised. To achieve this goal a state can rely on multilateral institutions, because once it becomes a member it will be constrained by their rules and norms. Ikenberry named it an 'institutional lock-in’ mechanism. ${ }^{36}$ Therefore, China’s overt willingness to join the WTO is a self-restraint strategy through which the country voluntarily constrains its trading policy and behaviour according to the rules and norms of the WTO as well as its commitments to it. Since the WTO has monitoring and trade dispute settlement mechanisms, China would be evaluated and constrained by WTO procedures and rules. For example, a special WTO procedure, the Transitional Review Mechanism (TRM), was established to review China's compliance with the agreements it had signed after its accession. In addition, other countries can file disputes and complaints against China's trading practices through various WTO channels. These rules and constraints are all unprecedented for China. Therefore, China's willingness to join the WTO reflects a self-restraining effort to strengthen its commitment as an 'integrator' to the outside world.

In addition, China actively participated in other trading liberalization regimes, such as the Asia Pacific Economic Conference (APEC), through which China reconfirmed its trade liberalization commitments. China has become an active APEC member since joining in 1991, promoting regional trade liberalization and economic cooperation among Asian-Pacific countries. It should be noted that APEC is different from the WTO in that the latter has binding function and dispute settlement mechanisms, while the former is voluntary in nature. However, China's trade liberalization efforts in the APEC also strengthen its commitments to the WTO. For example, in the 1994 Bogor APEC summit, China and other APEC members set up a timetable for achieving 'free and open trade and investment in the Asia-Pacific no later than the year 2020'. In the 2001 Shanghai APEC summit, China initiated a call for a new round of multilateral trade negotiations to reinvigorate the world economy through the 'Shanghai Accord'.

Although the APEC agreements do not have such a binding effect on its members' behaviour as those of the WTO, they at least serve as a testing ground for China to reassure members of its trade liberalization efforts and promises. It is true that China may not be punished materially even if it fails to keep its promises to the APEC. However, as an institution, the APEC

\footnotetext{
36 See Ikenberry, After Victory.
} 
entails similar 'shadow of the future' and 'issue-linkage' effects on state behaviour. This suggests that China's failure to keep its APEC commitments would have negative impact on China's future cooperation (shadow of the future) or cooperation in other areas (issue-linkage) with other nations. Therefore, by relying on the self-restraint strategy through multilateral institutions China's intent has been to convince the outside world of its sincerity and resolve with respect to its new role as 'integrator' rather than 'outsider' in the system.

\section{Role Diversification}

It should be noted that China's accession to the WTO was only its first step towards socialization into the West-dominated trading system after the Cold War. Although China joined the WTO in 2001, the country still strived to gain its 'market economy status' (MES) from leading economies such as the United States and the European Union. Without MES, Chinese companies would be placed in a disadvantageous situation when trading with other countries because they could be subjected to accusations of dumping goods in overseas markets. According to the WTO anti-dumping law, a non-MES country cannot use its domestic price as a reference amid a dispute when determining the normal values of the products in question. Instead, the investigating country relies on a third party's (the so-called surrogate or analogue country) price to determine whether or not the products have been sold at the dumping price.

Therefore, the non-MES country is normally vulnerable in anti-dumping investigations. ${ }^{37}$ Since its WTO entry, China has been a major target of anti-dumping cases initiated by the United States and the European Union. Owing to its non-MES, China lost almost all these cases in the WTO.

Although China treats the WTO as the major venue through which to confirm its 'integrator' role, this is by no means its only one. China has actively diversified its NRCs through both bilateral and multilateral trade agreements in the regional setting. Since 2005, China has signed 11 free trade agreements with other nations and regional organizations, such as ASEAN. Currently, China has 14 free trade partners comprising 31 countries. It should be noted that WTO rules permit the signing of bilateral or regional free trade agreements. Because of the stalled progress of trade liberalization negotiation in the WTO, especially the Doha Round, many

\footnotetext{
${ }^{37}$ See Christian Tietje and Karsten Nowrot, 'Myth or Reality? China’s Market Economy Status Under WTO AntiDumping Law after 2016’, Policy Papers on Transnational Economic Law, no. 34 (2011).
} 
countries chose to pursue bilateral and multilateral free trade agreements as an important supplementary or even alternative tool to promote trade and economic cooperation.

In pursuing free trade agreements, China abandoned the passive 'integrator' role it once played in the WTO. Instead, China set up a new NRC as an 'initiator' in prompting these free trade agreements with other nations. For example, China proposed and signed the Framework Agreement on China-ASEAN Comprehensive Economic Cooperation at the sixth China-ASEAN Summit in November 2002. In November 2004, Chinese signed the Agreement on Trade in Goods of the China-ASEAN FTA effective in July 2005. In order to reach an FTA with ASEAN, China made a generous offer to ASEAN, called the 'early harvest' plan, which allows the ASEAN countries to export certain products to China under reduced tariffs and duties before the FTA takes effect. In other words, China promised to open its domestic market for certain products from ASEAN while allowing ASEAN countries to protect their markets before the FTAs were established. This attractive offer would definitely provide more economic benefits and reduce social and economic costs for ASEAN countries, at least in the short run, even though market forces would decide the long-term economic gains or losses.

This 'initiator' role that China exercised in the FTAs is different from its passive 'integrator' role in the WTO, in that China does not need to wait for acceptance from existing members. Instead, China can take the lead and enjoy full control over the progress and procedure when negotiating with other nations. Currently, China has three FTAs under negotiation and three other FTAs under consideration. Given the fact that China has overtaken the United States as the largest trading nation in the world since 2013, it will be no surprise if other nations seek FTAs with China in the future.

This 'initiator' role successfully diversifies China's options of liberalizing its economy and promoting trade and investment with other nations. As the Chinese Ministry of Commerce states, the FTAs provide 'a new platform to further opening up to the outside and speeding up domestic reforms, an effective approach to integrate into global economy...” ${ }^{38}$ In other words, through diversifying the NRC from 'integrator' in the WTO to 'initiator' in the FTAs, China creates more channels and paths to integrate itself into the world economy and international society.

\footnotetext{
${ }^{38}$ See the official website of China's FTAs at the Chinese Ministry of Commerce, http://fta.mofcom.gov.cn/english/index.shtml
} 


\section{Alter-casting}

As mentioned earlier, existing members normally conduct an alter-casting strategy towards the novice through which they can impose a certain role or expectations on a new member. However, a new member can also use this strategy to legitimize their desired roles or behaviour. In the WTO, China's best use of the alter-casting strategy has been to file disputes against the United States through WTO procedures and rules. For example, in March 2002 China was involved in a multi-party trade dispute against the United States regarding US trade protection measures on some steel products. The WTO investigation concluded that US safeguard measures in this dispute were inconsistent with the United States' obligations in the WTO. In December, therefore, the United States was forced to terminate all of the safeguard measures subject to this dispute. $^{39}$

However, China’s WTO fights have not always been successful. In September 2012, China filed a dispute against the US with regard to its countervailing and anti-dumping measures on certain Chinese products. In 2014, the WTO investigation panel rejected China's claims that the US 'public law 112-99' signed by President Obama in March, 2012 broke WTO rules. The US 'public law 112-99' is a piece of legislation that explicitly allows the application of countervailing measures to non-market economy countries. The WTO panel's decision thus allowed the United States to sustain its countervailing measures against Chinese products. In the words of the US Trade Representative, 'the WTO panel's decision to reject China's challenge to our law is a significant victory for the United States ${ }^{40}{ }^{40}$ However, the WTO investigation panel also found that the US Department of Commerce (DOC) had been wrong to impose double duties on Chinese products in 25 anti-dumping and countervailing duty investigations against China between 2006 and 2012. Both the United States and China filed appeals against the panel's decision. The final results of this dispute case are still pending. ${ }^{41}$

Since the WTO rules and procedures were mainly set by Western countries before China joined the organization, China is not familiar with them in the first place. However, after joining the WTO, China started to use these prevailing rules to legitimize its claims and behaviour by filing disputes against the United States and other countries. It appears that there is still a long

\footnotetext{
${ }^{39}$ For this trade dispute, see http://www.wto.org/english/tratop_e/dispu_e/cases_e/ds252_e.htm

40 Tom Miles, ‘China Loses WTO Bid to Overturn US Law Against Unfair Subsidies’, Reuters, 27 March, 2014.

${ }^{41}$ For details about this dispute, see http://www.wto.org/english/tratop_e/dispu_e/cases_e/ds449_e.htm.
} 
way for China to go before it learns how to 'play the game'. Alter-casting the United States in a 'violator' role by using the rules set by the United States is by no means an easy job for China, now or in the future.

\section{China's Rise and Dynamic Models of Role Transition}

Since 2008, Chinese assertive diplomacy has come under harsh criticism. Examples of China's assertiveness include the country's refusal to revalue its currency, an uncooperative attitude on climate change in Copenhagen, reluctance to punish North Korean and Iranian provocations against the international order, and tough actions toward its weak neighbours in the South China Sea. ${ }^{42}$ Bearing in mind the US high-profile 'pivot to Asia' in 2010, it seems that a new Cold War between China and the United States may be on the horizon.

However, from a rational bargaining and role theory perspective we suggest that it is still too early to predict an inevitable 'coming conflict' between China and the United States. The current turbulence in US-China relations may rather be seen as a new bargaining process between the two states. It is rational for China, with its increasing economic and military power, to bargain with the United States for new terms. Although it will be by no means easy, if they adopt the right bargaining strategies it is still possible for both to avoid conflicts and achieve a new bargaining equilibrium. After examining the effects of China's 'assertive diplomacy' under the leadership of Xi Jinping, Xuetong Yan suggests that China's assertiveness actually helped China improve bilateral relations with most countries, including the United States, after $2012 .{ }^{43}$ Although the foreign policy implications of China's assertive diplomacy or new 'striving for

\footnotetext{
${ }^{42}$ For an excellent review of perceptions of China's assertiveness, see Michael Swaine, 'Perceptions of an Assertive China’, China Leadership Monitor mo. 32 (2010); Michael Swaine, ‘China’s Assertive Behavior-Part One: One “Core Interests”, China Leadership Monitor no. 34 (2011); Michael Swaine and M. Taylor Fravel, 'China’s Assertive Behavior-Part Two: The Maritime Periphery’, China Leadership Monitor no. 35 (2011). For China’s assertiveness in the South China Sea, see Jane Perlez, 'Beijing's Exhibiting New Assertiveness in South China Sea', The New York Times, 31 May (2012). For an excellent evaluation of China's assertiveness discourse, see Alastair Iain Johnston, 'How New and Assertive Is China's New Assertiveness?’ International Security 37, no. 4 (2013), 748.

${ }^{43}$ Yan Xuetong, 'From Keeping a Low Profile to Striving for Achievement', The Chinese Journal of International Politics 7, no. 2 (2014): 153-184.
} 
achievement' are still debatable, it is clear that China's policy choices indeed shape the dynamics of power and role transitions between China and the outside world.

The four strategies suggested in this paper cannot guarantee a peaceful rise of China. However, if China uses these four strategies wisely, it can at least create conditions for a possible peaceful role transition in the international system. China had proclaimed a 'peaceful rise' since 2002 but changed it to 'peaceful development' in 2004. The change in terminology from 'rise' to 'development' indicates the sensitivity of the Chinese leadership towards the outside world. In other words, China does not want to become a 'challenger' in rising, but rather a 'partner' in development.

However, in the eyes of other states 'peaceful' is the key word, i.e., the way that China will adapt to change the world. Therefore, China needs to signal the outside world as to how it will rise or develop in the future. Territorial disputes in the South China Sea and the East China Sea between China and its neighbours are widely seen as possible flash points of future military conflicts in the Asia Pacific. If China can creatively resolve a territorial dispute, its signal of 'peaceful rise' or 'developer' role will be more credible in the eyes of the outside world.

Second, China needs to restrain its behaviour through multilateral institutions. As in the WTO, China has to convince the outside world that it is a good citizen in compliance with rules and norms in the security-oriented institutions. Negotiating a code of conduct with ASEAN in the South China Sea could be the first step. In addition, China will need to consider how to build an EU-type security community in Asia in the long run, so that it can seal its peaceful intentions more effectively through multilateral institutions.

Third, China needs to diversify its roles in international society. It is true that the SinoUS relationship is the most important bilateral relation for a rising China. However, China needs to go beyond the US-centric, decision-making model. In its role conceptions China needs to set up multiple roles with reference to the United States beyond the 'partner' or 'challenger' roles. China needs to establish new roles, such as becoming a 'peace keeper' in Africa, a 'deal broker' in the Middle East, or a 'power balancer' in Europe. The diversification of China's roles means that China will take more responsibilities in world affairs. However, with more power come more responsibilities. If China shirks the responsibilities that a role entails, it will be neither respected nor accepted by the outside world.

Last, China can legitimize its rising pursuits and behaviour through an 'alter-casting' strategy. China can make use of the prevailing existing norms and rules to justify its behaviour 
through persuasion rather than impose it by coercion. This is not easy, since most norms and rules are designed and established by already existing powers to protect their own interests. In order to be accepted by international society in a peaceful way, China needs first to learn how to live with the existing norms. After learning how to 'play the game', China can gradually push to change the rules and norms of the game and achieve another role transition from 'rule taker' to 'rule maker'.

It is not easy for the outside world, especially the United States, to accept China's new role as either 'partner' or 'challenger'. This is a normal reaction towards a newcomer, especially when they have the potential to be the future world leader. However, merely denying and demonizing China cannot stop China’s rise. It would be wise for the outside world, especially US policymakers, to take China's role-bargaining efforts seriously and consider how to reach a negotiation deal with China. ${ }^{44}$ One vivid example is the recent development of the Asian Infrastructure Investment Bank (AIIB).

In 2013, China initiated the establishment of the AIIB to facilitate and finance infrastructure projects in the Asia Pacific. For China, the AIIB is a typical practice of the role diversification strategy. Because China's pursuit of more voting power in the International Monetary Fund was blocked by US Congress, China had to change its "integrator" role to become a "competitor" toward the current international financial system. ${ }^{45}$ Because the AIIB would challenge US-led world financial institutions including the IMF and the World Bank, as well as the Japan-led Asian Development Bank, the United States strongly opposed the AIIB from the beginning. It is no secret that the United States lobbied its Asian allies, such as Japan, South Korea, and Australia, to stay away from the AIIB. However, US financial 'containment' against the AIIB started to collapse in early March, 2015, when Great Britain announced its intention to join the AIIB as a founding member. Three more European countries, France, Germany, and Italy, soon followed suit, as did Australia and South Korea, two US allies in the

${ }^{45}$ Andrew Soergel, ‘Amid U.S. Paralysis, China Cashing’, US News, June 10, 2015, http://www.usnews.com/news/articles/2015/06/10/asian-infrastructure-investment-bank-chinas-answer-to-westernmarginalization 
Asia Pacific. By the end of March, a total of 46 countries formally applied for membership of the AIIB, even though the United State still said 'no' to this China-led financial institution. ${ }^{46}$

This example can be seen as a typical failed negotiation or bargaining case on the part of the United States regarding China's rise whereby China established a new institution to challenge the existing United States-led liberal order. The AIIB outcome reflects a diplomatic failure of bargaining between the United States and China. As former Secretary of State Madeleine Albright later pointed out, 'We (the United States) should not have done it this way.' ${ }^{47}$ US policymakers would be wise to take China's bargaining efforts seriously and consider reaching a bargaining deal that both accommodates China's rise and protects its vital national interests. ${ }^{48}$

The outside world, especially US policymakers, would also be wise to take China's rolebargaining efforts seriously and consider how to reach a negotiation deal with China. Through bargaining, the outside world can signal its role expectations of China which may shape, modify, and even re-define China's role conceptions in the future international society. It is still early to predict what will happen about the unsettled negotiations between China and the outside world. To paraphrase Alexander Wendt, ${ }^{49}$ the peaceful rise of China is not given, but 'what states make of it'.

\section{Conclusion}

In this paper we have illustrated four strategies from rational choice theory and role theory: costly signalling, self-restraint, role-diversification, and alter-casting, for a rising power to

\footnotetext{
${ }^{46}$ Jane Perlez, 'Stampede to Join China’s Development Bank Stuns Even Its Founder', The New York Times, April 2015. http://www.nytimes.com/2015/04/03/world/asia/china-asian-infrastructure-investment-bank.html?smid=twshare\&_r=1

${ }^{47}$ David R. Sands, 'Democratic titans say Obama “screwed up” and gave rise to China’s new bank', The Washington Times, April 1, 2015 http://www.washingtontimes.com/news/2015/apr/1/efforts-to-head-off-chinadevelopment-bank-called-l

${ }^{48}$ For arguments for accommodating China’s rise, see Charles Glaser, 'Will China’s Rise Lead to War? Why Realism Does Not Mean Pessimism', Foreign Affairs 90, no. 2 (2011), 80-91; Hugh White, The China Choice: Why America Should Share Power (Collingwood: Black Inc. 2012); Amitai Etzioni, 'Accommodating China', Survival
} 55, no. 2 (2013), 45-60.

${ }^{49}$ Alexander Wendt, 'Anarchy is What States Make of it', International Organization, 46 (1992), 391-425. 
bargain for a peaceful role transition in an international society. An examination of China's WTO accession and integration into the global economy has showed how China employed these four strategies to transform its role from that of 'outsider' to 'integrator' in the WTO and then to 'initiator' in the FTAs. It should be noted that China's role transition dynamics entail many aspects, and that economic transition may be a relatively easy one, especially compared to changing China’s roles in the security and foreign policy domains.

Moreover, China's bargaining strategy is not the only factor that determines the outcome of the negotiation process, because other actors in the outside world will certainly bargain against China's attempts. The key issue here, however, is that as a rising power China might need to move first. Whether the negotiations between China and the hegemon can be successful will largely depend on China’s bargaining strategies as well as negotiations between China and the outside world. Based on the findings of this study, the focus of future research could be on how the United States or other states bargain against China's changing role in the process of power transformation in the post-unipolar world.

Theoretically, this paper suggests that rational choice theory and role theory offer guides to 'best practices' for policymakers who want to continue or alter the status quo relations between states. 'Practice' is a focus in general international relations theory that has appeared over the past decade as a response to post-structural schools of international relations theory, including constructivism and post-modernism. It refers to the study of 'habit' as the customary actions between states that regulate their behaviour towards one another and presuppose a background of common understanding regarding the meaning and normative appropriateness of these actions as a competent performance in specific circumstances. ${ }^{50}$ Role theory's focus on performing roles and counter-roles overlaps partly with the normative thrust of 'practice' or 'habit' as normative actions identified by Emanuel Adler and by Adler and Vincent Pouliot. ${ }^{51}$ 'Best practices' here refer to those strategies and tactics identified in role theory as actions managing the interplay of power, interests, and identity in patterns of cooperation and

\footnotetext{
${ }^{50}$ Emanuel Adler, ‘The Spread of Security Communities: Communities of Practice, Self-restraint, and NATO’s Post-Cold War Transformation', European Journal of International Relations, 14(2008): 195-230. Ted Hopf, 'The Logic of Habit in International Relations’, European Journal of International Relations, 16(2010): 539-561. Emanuel Adler and Vincent Pouliot, 'International Practices', International Theory, 3(2011): 1-36. Chris Brown, ‘The “Practice Turn”, Phronesis, and Classical Realism’. Millennium, 40(2012): 439-456.

${ }^{51}$ Ibid.
} 
conflict in world politics so as to maximize benefits and minimize costs for states in the role bargaining process. This perspective makes role theory a theory of rational choice wherein role enactment by self and others as patterns of strategic interaction under the direction of role conceptions and role expectations from role theory and the constraints of power and interests from rational choice theory collectively regulate bargaining strategies among states in the international system. How China and other states can use "best practices" through diplomacy to bargain for a peaceful role transition offers a new research agenda for both scholars and policy analysts in international relations in the future. 